\title{
Conservation and Wildlife Management-A Review
}

\author{
Sanjay Cyril Masih ${ }^{1}$ and Bhat Rayees Ahmad ${ }^{2 *}$ \\ ${ }^{1}$ Department of Zoology, Ewing Christian Post Graduate College, Allahabad, India \\ ${ }^{2}$ Department of Zoology, Kurukshetra University, Kurukshetra, India
}

*Corresponding author

\section{A B S T R A C T}

Keywords

Conservation,

Diversity and wildlife

Article Info

Accepted:

04 November 2019

Available Online:

10 December 2019
Presently conservation of biodiversity is of utmost challenge. It requires collaborative efforts for success in modern changing world. Thus, a great challenge has emerged to conserve and minimise the losses of the wildlife in the changing environment. Efforts of conservation with respect to wild life require a great deal of plan. This review highlights the major issues about wildlife life extinction, endangerment and conservation. Habitat conservation is the key solution to conserve biodiversity. Lot of efforts has been done to encourage forestation and decrease deforestation and practices has been done in many areas.

\section{Introduction}

Nation India is a vast nation with immense beauty possessing a rich heritage of wild animalse.g. tiger, lion, leopard, elephant, fox, bear, deer, rhinoceros are found in abundance. India has more types of the graceful deer and cats than any other country in the world. There are 120 families of terrestrial vertebrates in India. 400 species of mammals, 1200 species of Birds, 350 Species of Reptiles and more than 29,70,000 species of insects has been reported. "Wildlife management" may be defined for present purposes as "the management of wildlife populations in the context of the ecosystem. An important aspect to manage and conserve the wildlife is to conserve and protect their natural habitat (Lyster, 1985; Geist and McTaggert-Cowan, 1995; Moulton and Sanderson, 1999; Vasarhelyi and Thomas, 2003).

\section{Protected areas network}

Post independence India saw a spurt in developmental activities. As a result, more and more forest land gave way for agriculture, industry and infrastructure development. Rapid growth of human and livestock populations and consequent pressures on 
forest land took a heavy toll on the country's wilderness. This network has now grown to 606 Protected areas comprising of 96 national parks and 510 wildlife sanctuaries. This covers an area of 15.59 mha, making up about 4.8 percent of the geographical area of the country.

Although in numerical terms, the protected area(PA) network in India is reasonably large, the size-class distribution of PA network presents a different picture. Only 222 PAs are larger than $1000 \mathrm{~km}$ whereas 189 PAs or nearly 31 percent of the 2 2network is less than $10 \mathrm{~km}$. The mean size of the PA is 262 $\mathrm{km}$ which is extremely small compared to PAs in Africa and North America. The top five states in terms of PA numbers are Maharashtra (41), Madhya Pradesh (34), Himachal Pradesh (34), Rajasthan (28) and Andhra Pradesh (26). The top states in 2 2terms of PA coverage are Gujarat $(16,902.8 \mathrm{~km})$, Maharashtra $(15,426.3$ $\mathrm{km}), 2$ 2Jammu and Kashmir (14,242.5 km), Andhra Pradesh $(12,972.4 \mathrm{~km})$ and Madhya 2Pradesh $(10,814.8 \mathrm{~km})$. The 28 tiger reserves which have a special focus on 2protection extends over $37,761 \mathrm{~km}$ area and overlaps the area of PAs.

\section{Causes of extinction}

The main cause of wildlife extinction is as:

Habitat loss

Hunting

Wildlife trade, body parts etc.

Trade of wildlife in relation to research

Climatic changes

pollution etc.

poaching and shooting
De Silva (2016) has stated that main threat for Asian wildlife is habitat loss and legal/illegal trade.

\section{Values of wildlife}

Wildlife has an immense role in livelihood aspects. Various wildlife projects have high medicinal and spiritual values in different human cultures (Scoones et al., 1992). Bushmeat, in has an important benefit with related to forest dwelling populations. It is considered as easily transported from one place to another and also long preserved. For the forest dwelling population it serves as source of primary protein and economical purpose. Throughout tropical forest countries, many people benefit from wild meat: from those who eat it as part of a forest dependent subsistence life-style, to those who trade and transport it at all points along different supply chains, to those who consume it in restaurants and homes, often far from the forest.

\section{Economic values}

Scoones et al., (1992) have stated that the use of wildlife has important livelihood aspects and serves multiple roles. Wildlife products are often major items of consumption or display and have high medicinal and economical values which are transported from one place to other.

\section{Nutritional values}

In world-wide, wildlife and fish constitute animal protein in rural diets. Hladik et al., 1989, 1996 and Froment et al., (1996) in their studies have reported that wildlife provides significant calories to rural communities, as well as essential protein and fats. Hunting and gathering remain important to a high proportion of rural households in tropical forests. Hunting has been reported to provide between 30 to $80 \%$ of the overall protein 
intake of rural households in Central Africa (Koppert et al., 1996) and nearly 100\% of animal proteins.

\section{Social and cultural values}

Wildlife and hunting are intimately linked to many cultures throughout the world's tropical forests even if in some cases the meat is only of minor nutritional importance. Important social and cultural values are linked to foods and medicines derived from wild resources. Therefore while hunting provides meat and income it also remains an important social and cultural tradition for many peoples (both in developed and in developing countries). In many cultures to be a hunter is essential in gaining respect, achieving manhood.

\section{Conservation measures}

For the preservation of species wild life management staff should have a correct idea about the exact habitat which the species under consideration needs.

Natural habitat of wild animals should be carefully protected.

Shooting and hunting of endangered species should banned.

Habitats of wild life should be improved by constructing water holes, saltlicks and by raising plantation of better and nourishing fodder grasses and trees.

\section{Some Indian Sanctuaries and National Parks}

The centrally-sponsored scheme "Development of National Parks and Sanctuaries" came into existence soon after the enactment of the Wildlife (Protection) Act, 1972, recognizing that protection and effective management of habitat is crucial for the conservation of the rich wildlife of the country. Under this scheme, the States were encouraged to set up Protected Areas (National Parks and Wildlife Sanctuaries). Over the years the PA network in the country has expanded to over 600 National Parks and Sanctuaries (96 National Parks and 509 Wildlife Sanctuaries) spread over most biomes and encompassing the habitats of a large number of flagship, threatened and endangered wildlife species. Protected area network in India represents a range of climatic, geo-morphological and geographical formations, harbouring rich biodiversity. The important national parks and sanctuaries of India are

Kaziranga Wildlife Sanctuary

Manas Wild life Sanctuary

Jaldapara Wildlife Sanctuary

Mundanthurai Sanctuary

Ranganthittoo Bird Sanctuary

Bandipur Wildlife Sanctuary

Cotigao Wildlife Sanctuary

Periyar Wildlife Sanctuary

Mudumalai Wildlife Sanctuary

Kolameru Bird Sanctuary

Guindy Deer Park

Sesan Gir

Sariska

ChilkaLake

Bharatpur Bird Sanctuary

Daachigam Wildlife Sanctuary 


\section{Funding support for wildlife conservation}

Government of India provides part financial support to the State Governments under certain Centrally-sponsored Schemes. The rest is borne by the State Governments from their own resources. These Centrally Sponsored Schemes include schemes for Development of National Parks and Wildlife Sanctuaries, Project Tiger, Project Elephant, Ecodevelopment.

\section{Project tiger}

'Project Tiger' one of the most ambitious conservation projects in the world, hardly has any parallel in terms of its scale, magnitude and diversity of field operations and challenges. Launched in 1973, based on the recommendations of a Task Force, set up by the then Prime Minister, Smt. Indira Gandhi, initially nine tiger reserves were identified to be covered under the project tiger. It has now increased to 28 PAs falling in 17 states across the length and breadth of the country.

This encompasses almost $37,761 \mathrm{~km}$ of tiger habitat in the form of forests, meadows, mountains and scrubland. In-principle approval has been given for setting up of eight more tiger reserves (Mudumalai WLS (TN), Anamalai Perambikulam WLS (TN-Kerala), Sanjay-Dubzi WLS (MP), Achanakmar WLS (Chattisgarh), Sitandai \& Udanti WLS (Chattisgarh), Satkosia (Orissa), Dandeli Anshi WLS (Karnataka), Kaziranga NP (Assam). The distribution of tigers and their density vary from state to state due to a number of ecological and human factors viz. the forest cover, terrain, natural prey availability, presence of undisturbed habitat and the quality of managerial efforts taken towards protection. The Project Tiger' adopts a holistic eco-system approach. Its core-buffer strategy and protection and development initiatives gave a new perspective to the concept of wildlife management in the country and have been a 'role model' for conservation. The tiger population in the country stands estimated at 3642, as per 2001- 02 estimate.

\section{Project elephant}

Project Elephant (PE), was launched in February 1992 to provide financial and technical support to major elephant states in the country for protection of elephants, their habitats and corridors. The project also envisaged addressing the issues of humanelephant conflict and welfare of domesticated elephants. The population of elephants in India has increased from about 25,000 in 1992 to over 28,000 in 2001. Five new Elephant Reserves, namely Sonitpur, Dihing-Patkai, KazirangaKarbi-Anglong, Dhansiri-Lumding and Chirang-Ripu have been recognized in addition to the existing reserves, altogether covering 11 elephant management ranges in India. Major activities under the Project include: habitat improvement, fire protection, land acquisition for consolidation of habitats and establishment of corridors, procurement of equipment (weapons, tranquillizing sets, wireless sets, vehicles, etc.) for protection, census of elephants, immunization of cattle on the forest fringe, payment of ex-gratia grant for damage to human life and property by elephants, construction of elephant-proof barriers, construction of patrolling tracks and camps, etc.

The activities taken up by the States under Project Elephant have been mainly the following

Strengthening protection against poaching of elephants for ivory.

Habitat "improvement" or "enrichment" through planting fodder species of elephants.

Provide ex gratia relief for farmers whose crops have been damaged by elephants, or ex 
gratia payment to kin of persons killed by elephants.

\section{Wildlife and biodiversity conservation}

There needs to be an assessment of the extent of livelihood dependence of local communities and their contribution to ecosystem and wildlife conservation (Table 1).

The area of PAs must be at least $5 \%$ of the geographical area of the country. Biodiversity conservation must be looked after by the forest department at the central as well as
State level, in coordination with other agencies.

In worldwide special attention is needed to conserve wildlife. The main threat of the wildlife is the habitat loss. Forest area is getting decreased which possesses a serious threat to the wildlife and many species are extinct and some facing the challenge of the extinction. Therefore there must be strict rules, policy initiatives, awareness, seminars, values of wildlife, government and non-government organizations which will aware people related to the benefits of the wildlife.

Table.1 Conservation areas

\begin{tabular}{|c|c|}
\hline National parks & $\mathbf{9 6}$ \\
\hline Wildlife sanctuaries & 510 \\
\hline Tiger reserves & 28 \\
\hline Elephant reserves & 25 \\
\hline Biosphere reserves & 14 \\
\hline Wetlands & 94 \\
\hline Mangrove areas & 38 \\
\hline
\end{tabular}

\section{References}

Lyster, S. 1985. International wildlife law. Groteius Publications ltd, Cambridge.

Geist, V. and McTaggert-Cowan, I., eds. 1995. Wildlife Conservation Policy. Deselig Press, Calgary.

Vasarhelyi, C. and Thomas, V.G. 2003. Analysis of Canadian and American legislation controlling exotic species in the Great Lakes. Aquatic Conservation: Marine and Freshwater Ecosystems 13:417-427.

De Silva S. Need for longitudinal studies of Asian wildlife in the face of crises. Global Ecology and Conservation. 2016; 6:276-285

Scoones, I., Melnyk, M. and Pretty, J. 1992. The hidden harvest: wild foods and agricultural systems: a literature review and annotated bibliography.
IIED, SIDA and WWF, London, UK and Gland, Switzerland.

Hladik, C.M., Hladik., A., Pagezy, H. Linares, O. F., Koppert, G.J.A. and Froment, A. (eds.), 1996.

L'alimentationenforêttropicale, interactions bioculturelles et perspectives de développement. Volume I: Les ressourcesalimentaires: production et consommation; Volume II: Bases culturelles des choixalimentaires et stratégies de développement. UNESCO, Paris.

Froment, A., de Garine, I., BinamBikoi, Ch. and Loung, J.F. (eds), 1996. Bien Manger et Bien Vivre: Anthropologie alimentaire et développementen Afrique intertropicale: du biologique au social. L'Harmattan ORSTOM, Paris.

Koppert, G., Dounias, E., Froment, A. and 
Pasquet, P. $1996 . \quad$ perspectives de développement. Consommationalimentaire dans trois Volume I, Les ressourcesalimentaires : populations forestières de la production et consommation. (Eds régioncôtière du Cameroun : Yassa, C.M. Hladik, A. Hladik., H. Pagezy, Mvae et Bakola. In L'alimentationenforêttropicale, interactions bioculturelles et O. F. Linares, G.J.A. Koppert et A. Froment), pp. 477-496. UNESCO. Paris.

\section{How to cite this article:}

Sanjay Cyril Masih and Bhat Rayees Ahmad. 2019. Conservation and Wildlife Management, A Review. Int.J.Curr.Microbiol.App.Sci. 8(12): 219-224.

doi: https://doi.org/10.20546/ijcmas.2019.812.031 